\title{
Microcephaly and congenital nephrotic syndrome owing to diffuse mesangial sclerosis: an autosomal recessive syndrome
}

Department of Paediatrics and the Kipper Institute of

Paediatric

Immunology,

Beilinson Medical

Centre, Petah Tiqua

49100, Israel

B Z Garty

Paediatric Nephrology

Unit, Beilinson

Medical Centre, Petah

Tiqva, and Sackler

Faculty of Medicine,

Tel Aviv University,

Israel

B Eisenstein

Pathology

Department,

Beilinson Medical

Centre, Petah Tiqva,

and Sackler Faculty of

Medicine, Tel Aviv

University, Israel

J Sandbank

The Genetics Clinic,

Mount Sinai Medical

Center, New York,

NY, USA

$S$ Kaffe

Department of

Paediatrics, Soroka

Medical Centre, Beer

Sheva, Israel

R Dagan

Neurology

Department,

Beilinson Medical

Centre, Petah Tiqva,

and Sackler Faculty of

Medicine, Tel Aviv

University, Israel.

N Gadoth

Correspondence to

Dr Garty.

Received 9 February 1993

Revised version accepted for

Revised version accepted for
publication 24 August 1993

Ben Zion Garty, Bella Eisenstein, Judith Sandbank, Sara Kaffe, Ron Dagan, Nathan Gadoth

\begin{abstract}
Three sibs born to consanguineous parents had congenital nephrotic syndrome, microcephaly, and psychomotor retardation. Pathology of the kidneys showed diffuse mesangial sclerosis with deposits of IgG and C3 in the mesangium and glomerular basement membranes. All three children died before the age of 3 years. Of 19 published cases of children with the association of congenital nephrotic syndrome and microcephaly, only four had histological evidence of diffuse mesangial sclerosis, and two of their sibs probably had the same disease. The association of nephrotic syndrome owing to congenital diffuse mesangial sclerosis, microcephaly, and mental retardation appears to be a distinct syndrome with an autosomal recessive mode of inheritance.
\end{abstract}

( $\mathcal{F}$ Med Genet 1994;31:121-125)

Congenital microcephaly is associated with a variety of pathological conditions, including chromosomal aberrations, metabolic diseases, intrauterine infections, postradiation injury, and chronic hypoxaemia. ${ }^{1}$ In its isolated form, it is usually inherited in an autosomal recessive mode $^{2}$ and is accompanied by severe mental retardation. Occasionally it is inherited in an autosomal dominant mode, and in these patients the retardation is usually milder. ${ }^{1-3}$
Nephrotic syndrome in the first year of life (congenital nephrotic syndrome) is rare. Infantile microcystic disease, or the Finnish type nephrotic syndrome, is the best documented form of the syndrome. ${ }^{4}$ Other known causes of congenital nephrotic syndrome are intrauterine infection, ${ }^{56}$ renal vein thrombosis, ${ }^{7}$ and mercury intoxication. ${ }^{8}$ Minimal change nephrotic syndrome, congenital focal glomerular sclerosis, membranous glomerulopathy, or diffuse mesangial sclerosis are uncommon causes of nephrotic syndrome in the first year of life. ${ }^{9-11}$

The association of congenital nephrotic syndrome, microcephaly, and mental retardation has been reported in 19 children, ${ }^{12-21}$ but only six of them had diffuse mesangial sclerosis (table). ${ }^{18-21}$ We report a family with three microcephalic children who had severe psychomotor retardation and congenital nephrotic syndrome owing to diffuse mesangial sclerosis.

\section{Case reports}

The family was of Jewish North African origin. The pedigree is shown in fig 1 . There were consanguineous marriages in generations III and IV-V. The father of the proband was the mother's uncle. Except for the proband and two of his sibs, there were no other family members with kidney disease or psychomotor retardation. The other five sibs, as well as the parents, were healthy and did not have microcephaly. The mother of the proband did not smoke and had not taken medication or alcohol

Clinical and pathological findings in the patients with congenital nephrotic syndrome owing to diffuse mesangial sclerosis and microcephaly

\begin{tabular}{|c|c|c|c|c|c|c|c|c|c|c|}
\hline Case & $\operatorname{Sex}$ & $\begin{array}{l}\text { Micro- } \\
\text { cephaly }\end{array}$ & $\begin{array}{l}\text { Onset of } \\
\text { nephr syn }\end{array}$ & $\begin{array}{l}\text { Kidney } \\
\text { histology }\end{array}$ & $\begin{array}{l}\text { Mental } \\
\text { retardation }\end{array}$ & $\begin{array}{l}\text { Neurological } \\
\text { symptoms }\end{array}$ & $\begin{array}{l}\text { Dysmorphic } \\
\text { features }\end{array}$ & $\begin{array}{l}\text { Age at } \\
\text { death }\end{array}$ & Notes & $R e f$ \\
\hline 1 & $\mathrm{~F}$ & + & $1 \mathrm{~d}$ & Mesangial sclerosis & + & Seizures & No & $3 \mathrm{mth}$ & & 16 \\
\hline 2 & $M$ & + & $6 \mathrm{~d}$ & $\begin{array}{l}\text { Diffuse mesangial } \\
\text { sclerosis }\end{array}$ & ? & $\begin{array}{l}\text { Decreased vision \& } \\
\text { hearing }\end{array}$ & $\begin{array}{l}\text { Wide set eyes; } \\
\text { small nose }\end{array}$ & $2 \mathrm{mth}$ & & 19 \\
\hline 3 & $\mathrm{~F}$ & + & $6 \mathrm{~d}$ & Mesangial sclerosis & & $\begin{array}{l}\text { Hypertonic arms; } \\
\text { seizures }\end{array}$ & $\begin{array}{l}\text { Floppy ears; contractures } \\
\text { of hands } \& \text { feet }\end{array}$ & $2 \mathrm{mth}$ & & 20 \\
\hline 4 & $M$ & + & $12 \mathrm{~d}$ & - & NM & NM & $\begin{array}{l}\text { Floppy ears; } \\
\text { hypertelorism }\end{array}$ & $1 \mathrm{mth}$ & $\begin{array}{l}\text { Sib of } \\
\text { case } 3\end{array}$ & 20 \\
\hline 5 & $M$ & + & $14 \mathrm{mth}$ & Mesangial sclerosis & Severe & $\begin{array}{l}\text { Seizures; hypertonic limbs; } \\
\text { poor head control; no } \\
\text { visual fixation }\end{array}$ & $\begin{array}{l}\text { Micrognathia; } \\
\text { large ears }\end{array}$ & $18 \mathrm{mth}$ & & 21 \\
\hline 6 & $F$ & + & $9 \mathrm{mth}$ & - & Severe & $\begin{array}{l}\text { Hypertonic limbs; seizures; } \\
\text { poor vision } \& \text { hearing }\end{array}$ & $\begin{array}{l}\text { Large ears; } \\
\text { small midface }\end{array}$ & $3 y$ & $\begin{array}{l}\text { Sib of } \\
\text { case } 5\end{array}$ & 21 \\
\hline 7 & $M$ & + & $1 \mathrm{mth}$ & $\begin{array}{l}\text { Diffuse messangial } \\
\text { sclerosis. IgG and } \\
\text { C3 deposit in the } \\
\text { mesangium }\end{array}$ & Severe & $\begin{array}{l}\text { Hypertonic limbs; poor } \\
\text { head control; strabismus; } \\
\text { poor vision \& hearing }\end{array}$ & $\begin{array}{l}\text { Large, low set, floppy } \\
\text { ears; sparse, thin hair; } \\
\text { micrognathia; bilateral } \\
\text { undescended testes }\end{array}$ & $2 y$ & $\begin{array}{l}\text { Consan- } \\
\text { guinity }\end{array}$ & $\begin{array}{l}\text { Present } \\
\text { report }\end{array}$ \\
\hline 8 & $\mathbf{F}$ & + & $1 \mathrm{mth}$ & Identical to case 7 & Severe & Identical & $\begin{array}{l}\text { Large, low set, floppy } \\
\text { ears; sparse hair }\end{array}$ & $15 \mathrm{mth}$ & $\begin{array}{l}\text { Sib of } \\
\text { cases } 7 \& 9\end{array}$ & $\begin{array}{l}\text { Present } \\
\text { report }\end{array}$ \\
\hline 9 & $\mathbf{M}$ & + & $1 \mathrm{y}$ & - & Severe & Hypertonic limbs & ? & $3 y$ & & $\begin{array}{l}\text { Present } \\
\text { report }\end{array}$ \\
\hline
\end{tabular}



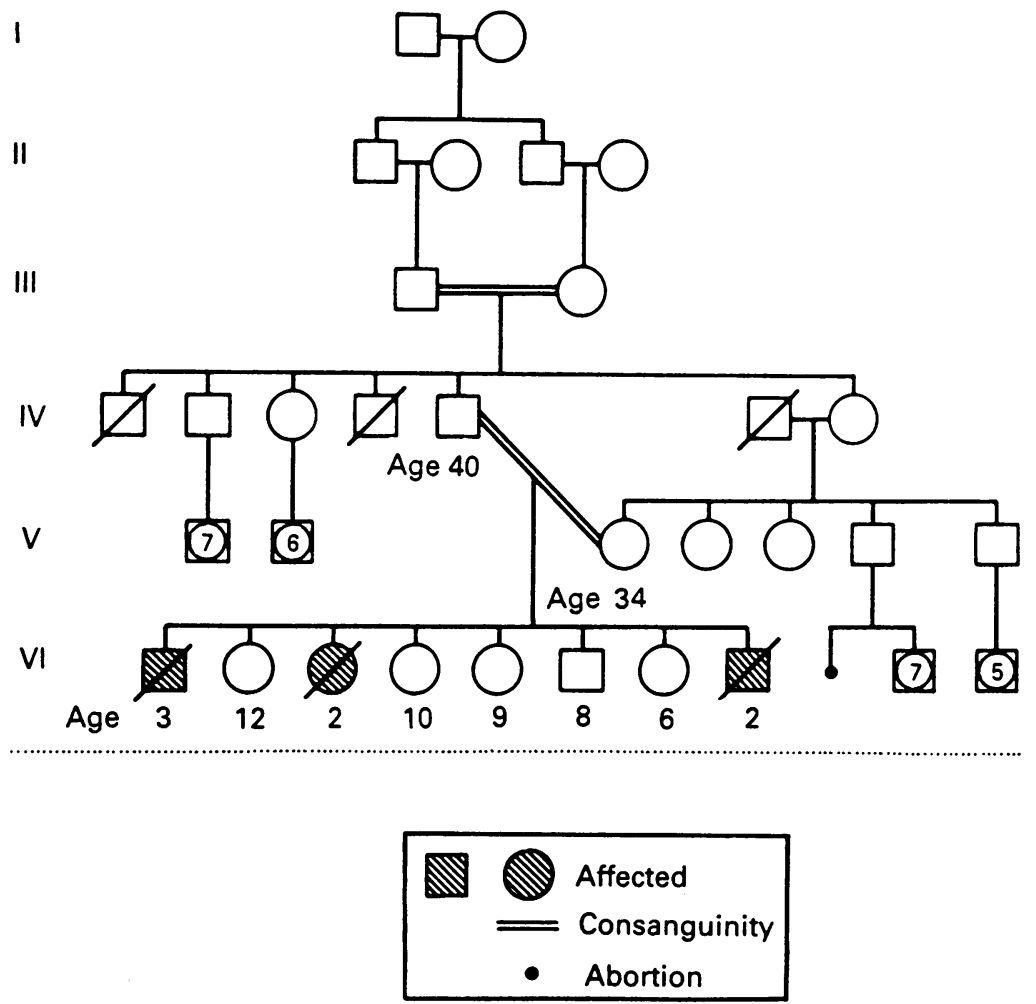

Figure 1 Family pedigree. proximal muscles, with a tendency to hypertonicity and scissoring of both legs. The fists were constantly clenched. Pain sensation was grossly intact and deep tendon reflexes were hyperactive with flexor plantar responses. The patient neither responded to noise nor followed objects with his eyes for more than a few seconds. Constant head rolling was present and he seldom smiled. Fundoscopic examination was normal.

Laboratory data showed haemoglobin $11.3 \mathrm{~g} / \mathrm{dl}$, white blood count $7 \times 10^{9}$ cells $/ 1$ (45\% neutrophils, $40 \%$ lymphocytes, $15 \%$ monocytes), platelets $460 \times 10^{9} / 1$, blood urea nitrogen $3.9 \mathrm{mmol} / \mathrm{l}$, and creatinine $35.4 \mu \mathrm{mol} /$ 1. Total serum protein measured $30 \mathrm{~g} / \mathrm{l}$, with albumin $19 \mathrm{~g} / \mathrm{l} ; \mathrm{C} 3$ component of the complement was $1.3 \mathrm{~g} / 1, \mathrm{C} 40.3 \mathrm{~g} / \mathrm{l}, \mathrm{CH} 5070 \%$. Cholesterol was $0.65 \mathrm{mmol} / \mathrm{l}$, triglycerides $0.75 \mathrm{mmol} / \mathrm{l}$, and total lipids $4.6 \mathrm{mmol} / 1$. IgG was $2 \cdot 3 \mathrm{~g} / 1$ (normal for age: $7 \cdot 2 \pm 2 \cdot 7 \mathrm{~g} / \mathrm{l}$ ), IgA $0.6 \mathrm{~g} / 1$ (normal: $0.7 \pm 0.3 \mathrm{~g} / 1$ ) $\mathrm{IgM} 1.3 \mathrm{~g} / \mathrm{l}$ (normal: $0.63 \pm 0.3 \mathrm{~g} / \mathrm{l})$. Urine analysis showed 5 to 10 erythrocytes in high power field and granular casts. Daily urinary protein excretion was 3.8 to $4.8 \mathrm{~g}$ (mainly albumin). Creatinine clearance was 100 to $105 \mathrm{ml} / \mathrm{min} / 1.73 \mathrm{~m}^{2}$.

The following laboratory tests were normal: serum sodium, potassium, chloride, calcium, phosphorus, magnesium, bilirubin, aspartate aminotransferase (SGOT), lactate dehydrogenase (LDH), creatinine kinase (CK), uric acid, $\mathrm{pH}$, lactate, pyruvate, $\mathrm{T} 4$, serology for rubella, toxoplasma, cytomegalovirus and syphilis, cerebrospinal fluid, electrocardiography, electroencephalography, and electromyography. The karyotype was of a normal male. Intravenous pyelography showed mild enlargement of both kidneys. Skull radiography disclosed a small cranium; the rest of the skeletal radiographic survey was normal. Bone age was 9 months. Cerebral CT scan showed a small posterior fossa with enlargement of the fourth ventricle and ambient cisterna compatible with cerebellar hypoplasia. There was also a mild degree of enlargement of the lateral and third ventricles (fig 2).

Percutaneous kidney biopsy showed hypercellularity of mesangial cells, an increase in PAS positive material in the mesangial matrix, and mild thickening of the capillary wall. Occasional segments showed obliteration of their normal structure. A few immature glomeruli were noted, as well as microcystic transformation of a few tubuli (fig 3). Electron microscopy of the glomeruli showed effacement of the epithelial foot processes and dilatation of the mesangium owing to hypercellularity and abundance of matrix. Electron dense deposits were present in the subendothelial region of the peripheral and axial glomerular basement membrane and in the mesangium. The lamina densa was irregular and sometimes thinner and sometimes thicker than usual (fig 4). Immunofluorescence staining showed massive deposits of IgG and $\mathrm{C} 3$ in the mesangium and glomerular basement membrane. These findings suggested the diagnosis of infantile diffuse mesangial sclerosis. The patient was discharged and was lost to detailed follow up. $\mathrm{He}$ cranial nerves were unremarkable. Mo amination showed muscle wasting without fasciculation and absence of purposeful movements. Strength was decreased mainly in the

Neurological evaluation disclosed poor head control, inability to sit up or turn, and absence of interest in his surroundings. The anterior fontanelle was small and barely palpable. The 


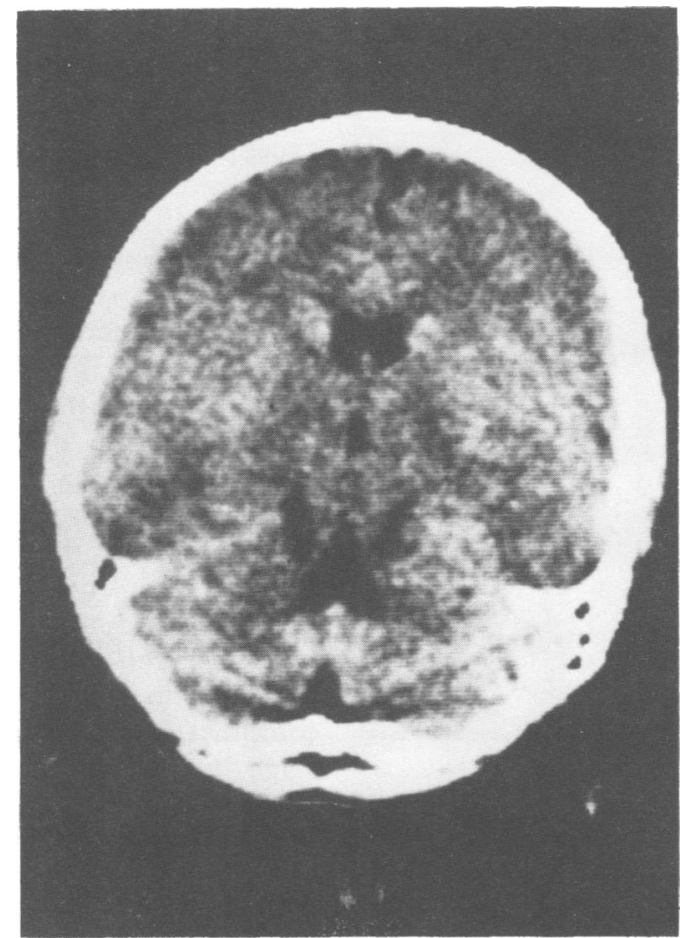

Figure 2 Cerebral CT scan showing enlargement of the fourth ventricle and cerebellar hypoplasia.

developed renal failure and died at the age of 2 years.

CASE 2 (VI.3)

The sister of case 1 , born at term after an uneventful pregnancy and delivery, was examined at the age of 12 months. Head circumference was $39.5 \mathrm{~cm}(-5 \mathrm{SD}$ below the mean for her age). There was poor head control and severe psychomotor retardation. Deep tendon reflexes were hyperactive and the limbs were
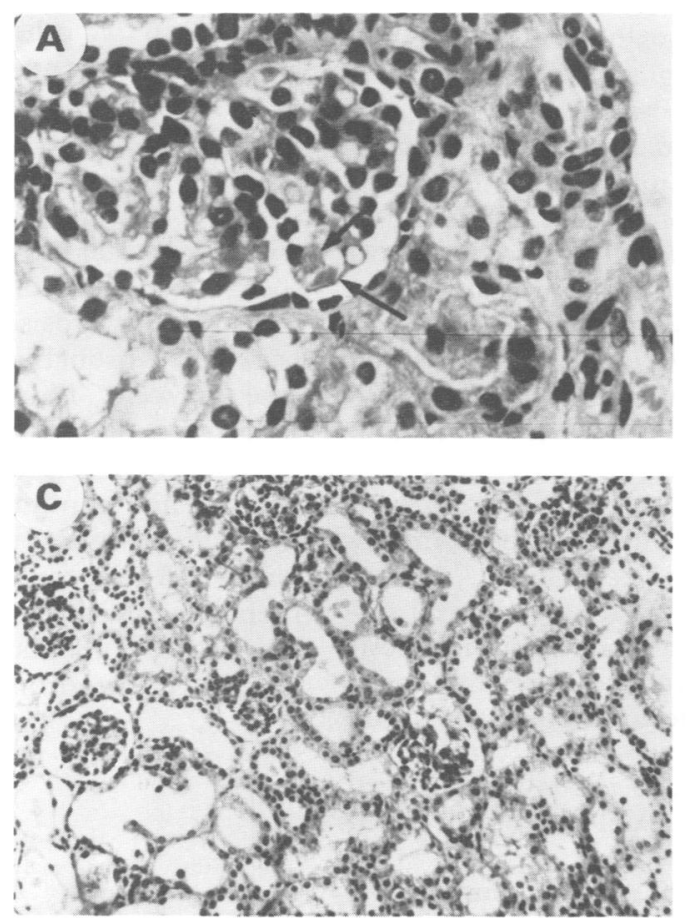
Figure 3 Light microscopy. (A) Matrix increase in glomerulus (arrows). (B) Focal increased cellularity in
glomeruli. (C) Tubular dilatation. (D) Fetal glomeruli (HE'E).

spastic. She could not turn and showed no interest in her surroundings or in social communication. Pitting oedema of the ankles and sacrum was present. She had strabismus, sparse hair, and large, low set, floppy ears, like her brother.

Laboratory tests showed hypoproteinaemia, hypoalbuminaemia, and hyperlipidaemia (total lipids were $1040 \mathrm{mg} / \mathrm{dl}$ ). Urine analysis showed massive proteinuria, microscopic haematuria, and granular casts. Kidney biopsy showed similar changes to those seen in case 1 . She was treated with $2 \mathrm{mg} / \mathrm{kg} /$ day of prednisone but without apparent effect. During the second year of life, rapid deterioration in kidney function occurred, and serum creatinine level reached $530 \mu \mathrm{mol} / 1$. She died at the age of 15 months of $E$ coli septicaemia. Necropsy could not be performed.

\section{CASE 3 (VI.1)}

This patient, the brother of patients 1 and 2 , also had a "little head", hypertonia of the limbs, severe psychomotor retardation, oedema, and proteinuria. His kidney function deteriorated gradually and he died before the age of 3 years. The clinical evaluation of this patient was performed at another hospital and kidney histology was not available.

\section{Discussion}

The characteristic features of congenital nephrotic syndrome associated with microcephaly are severe mental retardation, rapid deterioration of kidney function, unresponsiveness to medication, and usually fatal outcome before the age of 3 years. Nineteen cases of this association, first described by Galloway and Mowat, ${ }^{12}$ have been reported. ${ }^{12-21}$ Additional findings include neurological abnormalities,
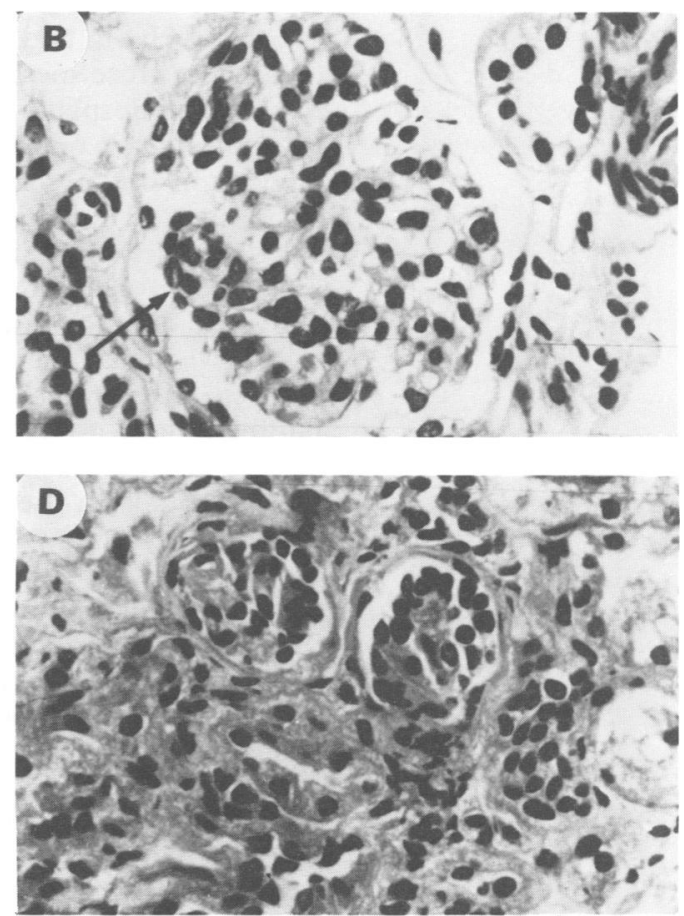


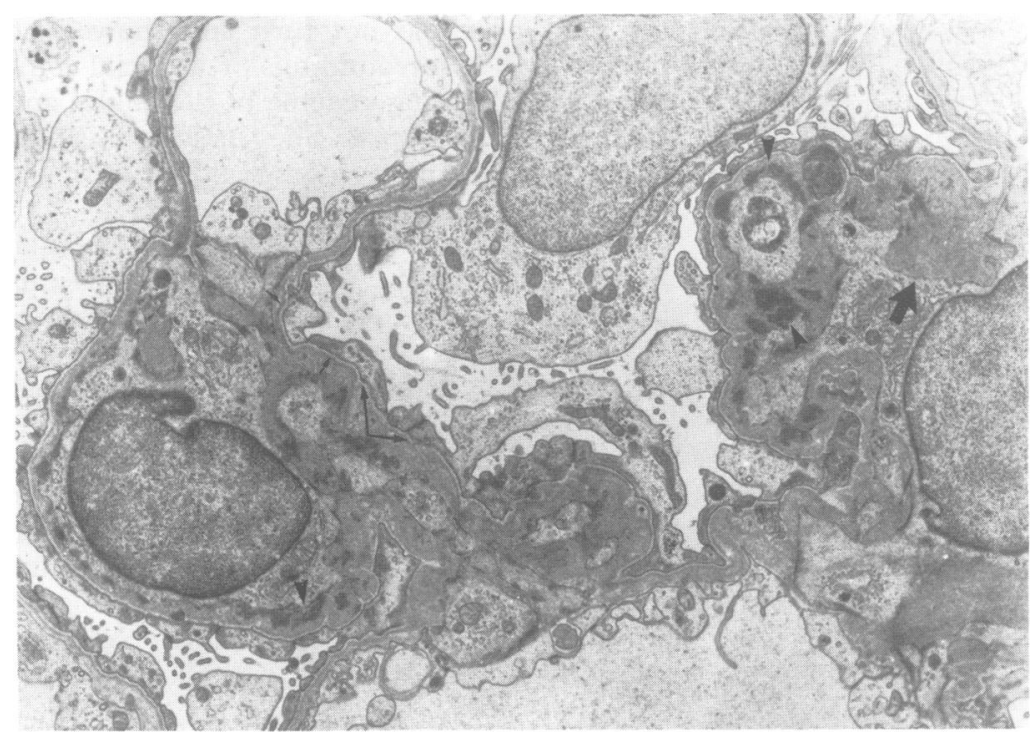

Figure 4 Electron microscopy of glomerular tuft showing subendothelial and paramesangial subendothelial deposits (arrow heads), increase in mesangial matrix (thick arrow), thinning of lamina densa (short thin arrows), and partial effacement of foot processes (long thin arrows). membrane. No immune complex deposits were mentioned in the other cases of congenital nephrotic syndrome and microcephaly, except for a patient with focal glomerulosclerosis reported by Roos et al, ${ }^{16}$ who showed deposits of IgM in the basal membrane of the capillary loops, and the patient with mesangial proliferation, reported by Cooperstone $e t$ al ${ }^{21}$ who had segmental distribution of fine granular deposits of IgM.

In patients with "isolated" congenital nephrotic syndrome owing to diffuse mesangial sclerosis (without microcephaly), occasional deposits of immune complexes were noted. For example, of three sibs with diffuse mesangial sclerosis one had mesangial deposits of IgG, IgM, C3, and fibrinogen, while the other two, although they had a similar kidney disease, had no demonstrable deposits of immune complexes. ${ }^{10}$ This may have related to the stage of disease or to its differing pathogenesis.

No specific metabolic abnormalities were found in our patients or in those previously reported. The neurological abnormalities and the mental retardation are probably secondary to the severe microcephaly and the abnormal brain structure. The mental retardation in cases of severe microcephaly is negatively correlated with brain volume, especially in patients with autosomal recessive microcephaly. ${ }^{2}$ Although brain histology was not available in our cases, brain CT scan suggested general atrophy, which was more pronounced in the subependymal zone, and cerebellar hypoplasia. In two previously reported patients with congenital nephrotic syndrome owing to diffuse mesangial sclerosis and microcephaly, the brain histology showed microgyria in the frontal, parietal, and occipital lobes $^{20}$ and pachygyria with neuronal ectopia. ${ }^{1820}$ The association of congenital kidney disease and neural migration defect was also reported in two other male sibs with glomerular kidney disease causing proteinuria and hydrocephalus. ${ }^{26}$ This may suggest a common insult during the first weeks of gestation affecting both the kidneys and the brain.

Four of the 19 previously reported children with congenital nephrotic syndrome and microcephaly had histological findings of diffuse mesangial sclerosis. ${ }^{18-21}$ Two sibs of these patients ${ }^{2021}$ probably had the same kidney disease as well. Thus, two of the previously reported patients were sporadic cases, and the other four were pairs of brothers and sisters born to non-consanguineous parents. ${ }^{2021}$ The fact that our three patients were sibs (two boys and a girl of a family of eight sibs) and that their parents were consanguineous, support the assumption of autosomal recessive inheritance of this syndrome.

We are indebted to Professor Mina Ben Bassat of the Pathology Department for her help and suggestions.

1 Ramirez ML, Rivas F, Cantu JM. Silent microcephaly: a distinct autosomal dominant trait. Clin Genet

1983;23:281-6.
Hecht F, Kelly JV. Little heads: inheritance and early detection. F Pediatr 1979;95:731-2.

3 Merlob P, Steier D, Reisner SH. Autosomal dominant 
isolated ("uncomplicated") microcephaly. f Med Genet 1988;25:750-3.

4 Huttunen NP. Congenital nephrotic syndrome of Finnish type: study of 75 patients. Arch Dis Child 1976:51:344-8.

5 Shahin B, Papadopoulou ZL, Jenis EH Congenital nephrotic syndrome associated with congenital toxoplasmosis. $\mathcal{F}$ Pediatr 1974;85:366-70.

6 McDonald R, Wiggelinkhuizen J, Kaschula ROC. The nephrotic syndrome in very young infants. $A m g$ Dis Child 1971;122:507-12.

7 Lewy PR, Wellington J. Nephrotic syndrome in association with renal vein thrombosis in infancy. $\mathcal{f}$ Pediatr with renal vein

8 Wilson VK, Thomson MC, Holzel A. Mercury nephrosis in young children. $B M F$ 1952;1:358-60.

9 Kaplan BS, Bureau MA, Drummond KN. The nephrotic syndrome in the first year of life: is a pathologic classificasyndrome in the first year of life: is a path
tion possible? $\mathcal{F}$ Pediatr $1974 ; 85: 615-21$.

10 Kristal H, Lichtig C. Infantile nephrotic syndrome. Clinopathological study of 11 cases. Isr $\mathcal{J}$ Med Sci 1983;19:62630 .

11 Habib R, Bois E. Heterogeneite des syndromes nephrotiques a debut precoce du nourrison (syndrome nephro-
tique infantile). Helv Paediatr Acta 1973;28:91-107.

12 Galloway WM, Mowat AP. Congenital microcephaly with hiatus hernia and nephrotic syndrome in two sibs. $\mathcal{f} \mathrm{Med}$ hiatus hernia and nephr

13 Robain O, Lyon G. Les micrencephalies familiales par malformation cerebrale. Acta Neuropathol (Berl)

14 Shapiro LR, Duncan PA, Farnsworth PB, Lefkowitz M Congenital microcephaly, hiatus hernia and nephrotic syndrome: an autosomal recessive syndrome. Birth $\mathrm{De}$

fects 1976;XII:275-8.
15 Metzke H, Bromme W. Kongenitale Mikrozephalie mit Muskelhypotonie und nephrotischem Syndrom. Pediat Grenzgeh 1982;21:39-41.
16 Roos RAC, Maaswinkel-Mooy PD, Loo EM, Kanhai HHH. Congenital microcephaly, infantile spasms, psychomotor retardation and nephrotic syndrome in two siblings. Eur $\mathcal{F}$ Pediatr 1987;146:532-6.

17 Kozlowski PB, Sner JH, Nicastri AD, Rudelli RD. Brain morphology in the Galloway syndrome. Clin Neuropathol 1989;8:85-91.

18 Robain $\mathrm{O}$, Deonna T. Pachygyria and congenital nephrosis disorder of migration and neuronal orientation. Acta disorder of migration and neuronal

19 Koskimies O, Sariola H, Holmberg C, Rapola J. Clinical quiz. Pediatr Nephrol 1991;5:433-5.

20 Gaudelus J, Leverger G, Rault G, et al. Association d'un audelus J, Leverger G, Rault G, et al. Association d'un
syndrome nephrotique a debut precoce et d'une microcephalie. Arch Fr Pediatr 1984;41:409-15.

21 Cooperstone BG, Friedman A, Kaplan BS. GallowayMowat syndrome of abnormal gyral pattern and glomerulopathy. Am f Med Genet 1993;47:250-4.

22 Mahan JD, Mauer SM, Sibley RK, Vernier RL. Congenita nephrotic syndrome: evolution of medical management and results of renal transplantation. $f$ Pediatr 1984 105:549-57.

23 Martul EV, Cuesta MG, Churg J. Histopathologic variability of the congenital nephrotic syndrome. Clin Nephrol 1987;28:161-8

24 Glastre $C$ Cochat $P$, Bouvier $R$, et al. Familial infantile nephrotic syndrome with ocular abnormalities. Pediatr Nephrol 1990;4:340-2.

25 Habib R, Loirat C, Gubler MC, et al. The nephropathy associated with male pseudohermaphroditism and Wilms' tumor (Drash syndrome): a distinctive glomerular lesion. Report of 10 cases. Clin Nephrol 1985;24:269-78.

26 Palm L, Hagerstrand I, Kristoffersson U, Blennow G Brum A, Jorgensen C. Nephrosis and disturbances of neuralonal migration in male siblings - a new hereditary disorder? Arch Dis Child 1986;61:545-8. 